\title{
CORRECTION: ROMANUL ROMÂNESC DIN VOIVODINA: TEME ȘI MOTIVE (ANNUAL REVIEW OF THE FACULTY OF PHILOSOPHY, 2016., VOLUME XLI-1, P. 311-322)
}

Fiecare literatură are începuturile ei și cele mai importante perioade sau curente literare, care vor reuni prozatori sau poeți în baza unor principii literare sau artistice. Fiecare curent se manifestă în baza unui program sau în baza unui manifest publicat în primul număr al revistei care face propagarea acestui curent literar. În literatura română din Voivodina acest lucru nu e valabil deoarece istoricii literari au fixat începutul literaturii române în deceniul cinci al secolului trecut prin apariţia primelor reviste literare. La fel istoricii literare nu consemnează existența a unui roman înainte de 1945. Dacă plecăm de la ideea oamenilor competenţi în domeniu, începutul romanului românesc din Voivodina se fixează abia în a doua parte a secolului trecut cu primele fragmente publicate în revistele de cultură de aici. În lucrarea de față încercăm pentru prima dată să facem o împărțire a romanului românesc din Voivodina și totodată să atragem atenția asupra temelor la care au apelat scriitorii de aici, dar și la motivele literare specifice satului bănățean românesc.

Cuvinte-cheie: roman, literatura română din Voivodina, motiv, temă

Despre apartenența scriitorilor români din Voivodina diferitelor graiuri românești și despre particularităţile limbii lor s-au ocupat mai pe larg cunoscuții lingviști români din Voivodina, care în cercetările lor au demonstrat că populaţia românească din Banat are la bază trei straturi dialectale: unul bănăţean, altul ardelenesc și altul oltenesc. În partea mare a satelor bănățene din Serbia se vorbește în grai, lucru care a influențat foarte mult operele scrise ale scriitorilor români care provin din aceste medii rurale. Uneori putem să presupunem de unde provine autorul, doar prin simpla lectură a romanelor lui. Vom înțelege că scriitorii români din Voivodina provin ori de la codru (din satele din jurul orașului Vârșeț), ori de la

* popovic.virdjinija@ff.uns.ac.rs

** Lucrarea de faţă este realizată în cadrul proiectului Jezici i kulture u vremenu i prostoru/ (Limbi şi culturi in timp şi spaţiu), nr. proiect 178002, finanţat de Ministerul de Invăţămant şi Ştiinţă din Serbia. 
pustă (din satele din jurul orașelor Zrenianin sau Panciova), sau din sate mixte (din jurul oraşului Belgrad), doar prin simpla analiză a lexicului folosit aici. Acest fapt aduce acestor romane o doză de autenticitate, fiind unice de acest fel în literatura română. La fel, în romanele scriitorilor români din Voivodina se poate observa o mare influență a limbii sârbe sau a culturilor popoarelor conlocuitoare aici, care în mare măsură au format personalitatea acestor scriitori, crescând și învăţând într-un mediu multinațional și multiconfesional. De aceea ei preferă să apeleze la elemente lexicale ale minorităților din Voivodina, pentru a reda cu cea mai mare autenticitate ideile presupuse.

Plecând de la opiniile primului şi unicului istoric literar din Voivodina, prof.dr. Radu Flora, care menționează că ,atât istoriatul cât și aspectele tematice ale folclorului literar în limba română din acest spațiu, privind din perspectiva de astăzi, dar și din trecut, au creat o expresie literară în spiritul creației populare de care trebuie ținut cont, considerând că aceasta reprezintă primul pas spre creația artistică din vremurile ulterioare" (Flora, 1976: 13-31). Vorbind despre influența literaturii populare asupra literaturii din Voivodina, în special asupra limbii vorbite aici, Radu Flora ne-a lăsat în moștenire foarte multe surse istorice și literare despre cele mai de seamă opere literare care au apărut în acest spațiu, axându-se, în special, pe operele despre care a scris în paginile ziarului „Libertatea” sau revistei „Lumina”. Cele mai de seamă opere în perioada de avânt a literaturii române din Voivodina provin de la aşa-numiții scriitori-țărani, „care au avut noima pasiunilor stridente și a culorilor locale" (Baba 2017: 28) care au produs, la început, o literatură angajată politic şi sociologic cu influențe socialist-realiste. Literatura din Voivodina s-a dezvoltat fără influențe din țara mamă, iar tendința de bază a acestei literaturi este ,sincronizarea cu fenomenul general românesc” (Agache, 2010: 2728). Primii scriitori care s-au impus cu romane erau cei care au îmbrăţișat scriitura în manieră tradiționalistă, pentru faptul că provenind din satele românești din Voivodina, au vrut să evoce viaţa personajelor romanelor strâns legată de viaţa de la sat, de mentalitatea și obiceiurile țăranilor bănățeni. Istoricii literari au fixat începutul literaturii române în deceniul cinci al secolului trecut prin apariţia primelor reviste literare. La fel istoricii literari nu consemnează existența a unui roman înainte de 1945. Dacă plecăm de la ideea oamenilor competenți în domeniu, începutul romanului românesc din Voivodina se fixează abia în a doua parte a secolului trecut cu primele fragmente publicate în revistele de cultură de aici. Un lucru foarte puțin cercetat în literatura română din Voivodina este romanul românesc și apartenența lui la curente sau mișcări/promoții literare, precum și temele și motivele la care apelează scriitorii români din Voivodina în scrierea romanelor lor. 
Primele fragmente de roman scrise în limba română apărute în paginile revistei „Lumina” (1952-1953) erau scriitorului Miu Mărgineanu (O zi însemnată, Fata cu ochii miraţi, Ulmii de la răspântie). $\mathrm{Cu}$ ecouri autobiografice autorul descrie viaţa și mediul liceal din perioada interbelică iar personajele principale fac parte din grupul de tineri care pledează pentru afirmarea originalităţii românilor din fostul regat iugoslav, pornind de la o viziune sămănătorist-tradiţionalistă, conform programului de la „Sămănătorul”, în care ,acționarea pentru răscolirea morală” a sătenilor români pentru care dascălii formați în România ar trebui să plădeze în activitatea lor didactică și educativă. Autenticitatea atmosferei se obsearvă din expresiile argotice folosite de romancier pentru a demonstra limbajul elevului din perioada interbelică descrisă în romane: ,autorul adesea s-a lăsat furat de amănunte neesențiale neavând măsura selectivă necesară în plăsmuirea unui tablou concis, real și mișcător. Se resimt aromele realist-tradiționaliste ale romanelor românești dintre cele două războaie" (Petrovici, 1977: 41-47). Scenele descrise în romanele lui Miu Mărgineanu sunt pline de ,erotism palid” iar trăirile psihologice apar estompate, nu au vigoarea dezlănțuirilor tinerești, [...] ci mai degrabă țin de conceptul de viață al romancierului” (Popa, 1977: 133-134). Tinerii minoritari care merg la școlile sârbești din Banatul sârbesc au aceleași drepturi ca și elevii sârbi, încât prin dialogul dintre ei, autorul a dorit să aducă la lumină adevăratul grai bănățean, cu calchieri lingvistice din limba sârbă și scrierea cu chirilice. Romanul Ulmii de la răspântie, apărut în anul 1996, cu o tentă reportericească adâncește viața patriarhală al satului românesc bănățean, redată prin detalieri etnografice, lexic regional și un surplus de sârbisme.

Dacă am vrea să caracterizăm literatura românească a deceniului şase sub raportul structurilor artistice, ar trebui s-o alăturăm unor variante moderne, în care observației obiective a realității sociale i se alătură o perspectivă a istoriei și deschidere spre arhetipul țăranului român. Astfel, romanele lui Mihai Avramescu, apărute la o distanță de aproape douăzeci de ani, Tinereţe frântă în 1953 și Mesajul în 1971, cu un suport realist, dar fără să se îndepărteze foarte mult de romanul de tip tradiționalist, descoperă nu doar apectele tradiției populare rurale prezente în aceste texte, ci și viziunea mitizantă asupra realităţii pe care o aduc ele. Aceste romane, în special primul, Tinerețe frântă, ,prin lumea personajelor, prin poziţia lor socială, prin comportamentul, mentalitatea lor, romanul ne trimite direct la capodopera romanului realist românesc Ion de Liviu Rebreanu. Ca și în romanul Ion, în Tinereţe frântă personajul principal se lasă pradă «glasului pământului»." (Mengher, 2000: 178). Prin imaginea satului bănățean de dinainte de război și apariția intelectualului, scriitorul nostru încearcă să aducă în prim plan și contradicții și conflicte reale, cu o doză de psihanaliză, precum și fapte mărețe, emoționante, ori fapte care duc la 
degradare morală, înfățișând iubirea ca pe o apropiere de idealurile materiale ale eroului, produs al mediului și societății în care trăiește. Romanul Tinerețe frântă înfățișează viața satului de dinainte de război. Sub raport tematic, preocupările epicii din această etapă a dezvoltării romanului românesc din Voivodina, se axează în jurul a câtorva teme fundamentale: relația individului cu societatea, iubirea față de pământ, formele de acțiune a societăţii asupra individului (problema puterii) specifice pentru viața într-o societate patriarhală. Romanul realist al lui Mihai Avramescu merge pe linia romanului lui Rebreanu, aceasta fiind și drumul literaturii din Voivodina: de a se sicroniza cu proza interbelică și postbelică din România, fără să se depărteze, totuşi, în linii mari, de nota de autenticitate dată acestor romane. Chiar dacă a existat o doză de optimism pentru literatura română din acest spațiu, romanul nu era o specie care ar fi preferată scriitorilor de aici. Totuși, romanul realist tradiționalist din Voivodina, „a cultivat cu precădere perspectiva omului social, vizând realitatea umană ca determinată și modelată de relațiile sociale" (Cosma, 1988: 60), fiind prima treaptă în dezvoltarea romanului care a dus spre începutul unor concretizări epice moderne, unde se restabilesc legăturile cu trecutul iar viitorul devine posibil.

Prin publicarea romanelor de tip neotradiționalist la Editura Libertatea din Panciova ale autorilor Miodrag Miloș (Încercarea de a zbura, 1988; Calea scorpionilor, 1989; Vânt de răsărit, 1996) și Florin Ursulescu (Peisaj cu nuci, 1988; Sfârșit de vară, 1999), în literatura română din Voivodina apare o altă temă interesantă pentru romancieri: colectivizarea agriculturii. Romanuele lui Florin Ursulescu aduc „o limbă română curată și atent nuanţată” (Popa, 1997: 283) prin care scriitori își exprimă adevărul, poveștile lor de iubire, cuplul îndrăgostit, țărani scoși din lanul de grâu și puși să se lupte cu cele mai intime sentimente. Personajele sunt în partea mare țărani iar locul de desfășurare a acțiunii este satul bănățean. Scriitorul este apreciat de Mircea Tomuș în „România Literară” (nr. 38, 21. septr. 1989) care remarcă tablourile în mișcare zugrăvite cu meșteșug, în care se conturează mişcări sufletești și morale pe diferite trepte de intensitate, „redarea culorii locale, a trăirilor, frământărilor personajelor" (Agache, 2010: 126). Imaginile eroilor lui Ursulescu sunt tipic romantice, semnificative pentru acest moment al romanului românesc din Voivodina, care accede acum la un regim mai generos, al artei şi al frumosului propriu-zis.

Primul care a încercat să scrie un roman ciclu în literatura română din Voivodina este Miodrag Miloș, care a dat literaturii române din Voivodina ciclul Râulenilor, un roman împărțit în trei părţi, unde și de data aceasta viața satului bănățean este o sursă de inspirație. Romanele lui Miodrag Miloș sunt considerate cele mai reușite în literatura română din Voivodina, oferind cititorului fapte istorice 
reale, viața policită și socială a românilor în perioada postbelică. În romanul Încercarea de a zbura, Miodrag Miloș, ,realizează o cronică romanțată [...] o frescă reconstitutivă a unui trecut apropiat" (Iovanovici, 1998: 42), în care populația bănățeană e bântuită de sărăcie și mizerie. În volbura acestor vremuri viețuiește un copil de la țară, care, nevoit să plece la școală, este transplantat în oraș. Cu o ușoară nostalgie după ambianța idilică rurală, eroul este supus supraviețuirii într-un oraș cu mii de feluri de oameni, unde îl poate scăpa de la prăpăd doar valorile morale, virtuțiile şi cinstea - caracteristici moştenite genetic de la părinţi. În placheta de amintiri Pe când creșteam (1985), se scoate în evidență o carte de vizită a momentelor de autenticitate istorico-socială din Banatul sârbesc și Banatul românesc iar în momentul apariţiei romanului Vânt de răsărit, cititorii s-au putut bucura de o decriere extraordinară a spațiului voivodinean, cu destinul eroilor în prin plan. Apărând condiţia literaturii realiste, Miodrag Miloș consideră că proza nu ar avea niciun înţeles în afara unor noţiuni ca istorie, adevăr, realitate și abordează teme morale şi existenţiale într-un stil epic de mare densitate, care a așezat proza românească pe terenul solid al observaţiei psihologice. Începând cu romanul Calea Scorpionilor, care prefigurează motive, întâmplări și personaje din roman, care trădează preocuparea scriitorului pentru destinul ţăranului român, în perioada celui de-Al Doilea Război Mondial, „,ând detașamentele de eliberare naţională colaborau cu frontal sovietic împotriva fascismului” (Popa, 1997: 277). Faptele istorice recurente în roman sunt privite din perspectiva adevăratului martor al lor, fără imaginar și mistificări. „Romanul este plin de viață, creând o realitate sublimată, reflectată în metatext" (Ibidem) iar faptele etnografice ale satelor bănățene scot la iveală adevăratele deprinderi ale țăranilor români din Banat: „Râulenii făceau ce făceau, economiseau tot anul, se împrumutau sau se regăseau în alte moduri, numai şi numai să petreacă sărbătorile după datină: să nu lipsească de la masă colacii, păcăriile, sau șunca, cârnațul și alte mâncăruri ocazionale. Acum simțeau că sărbătoarea Crăciunului o să le fie mai săracă decât oricând. Nu numai că nu lipseau alimentele de care-i storseseră rușii în timpul staționării în sat, dar se zvonea că noile autorităţi nu vor permite sărbătorirea nașterii Domnului în care, de veacuri, își vedeau salvarea, mai ales în timpurile grele" (Miodrag Miloş). Prin cele trei cicluri din seria Râulenilor, volume fundamentale a prozei românești din Voivodina, Miodrag Miloş continuă tradiţia romanului românesc de inspiraţie rurală şi în acelaşi timp se distanţează de aceasta, propunând o viziune nouă, modernă asupra universului existenţial rustic și asupra ţăranului român, dar mai ales prin proza lui Miodrag Miloș ,,se poate constitui [o] autentică istorie mentală și spirituală a satului bănățean” (Filip, 1998: 20) cu un ,prețios material etnografic” și cu un limbaj „cu grijă cultivat, aproape impecabil din punct de vedere stilistic" (Ibidem). Alte teme 
aduse în dezbatere reprezintă și unele linii de forţă ale gândirii scriitoricești a lui Miodrag Miloș: raportul individului cu istoria, libertatea și constrângerea, iluzia și realitatea, solidaritatea umană și exilul interior, tema paternităţii, cea a cunoașterii, a iubirii și a morţii. Miodrag Miloș creează în ciclul Râulenilor, o impresionantă frescă socială, situând în antiteză perioada eliberării naționale, surprinzând pe lângă faptele istorice și unele de natură politică sau socială (echipe de activiști, sloganuri populiste, prigoana chiaburilor, compania de cooperativizare, colonizarea cu familii bosniece):

- Ce să fie. Cu schimbările astea, de toate. Lumea nu le aprobă cu una cu două. Se „vorbește şi de luarea pământului. Asta-i doare mai mult pe oameni. Să-ți ia pământul aşa, dintr-o dată, agonisit o sută de ani cu sudoarea și munca întregii familii. Asta nu-i totuna. Îți rupe din inimă, că pământul e parte din inima paorelui.

Este un roman polemic ce-și propune să descopere complicaţiile necunoscute ale sufletului ţăănesc, firea contemplativă, patimile, nevoile țăranului român cu o doză de ură și spirit de revoltă față de regimul comunist: „-Ați auzit, oameni? Ei și-au lăsat în Bosnia case, pământ, marvă și pluguri pe mâna bătrânilor și au venit aici să li se dea case și pământul nostru. Nouă ni se ia și lor li se dă. Iaca dreptate. Măi oameni, veniturile astea fac proști din noi”. Un alt plan epic este planul destinului comunităţii țărănești dinamizat de conflicte puternice: politic, economic, moral, romanul fiind un zguduitor document despre tragedia satului românesc tradiţional bănăţean colectivizat forţat.

Un moment foarte important în dezvoltarea romanului românesc din Voivodina este apariția primelor romane moderne ale lui Radu Flora și Traian Doban la Editura Libertatea din Panciova. Romanele Pierduţi în vijelii (1985) şi Mireasma iluziilor (1989) scrise de Traian Doban, aduce în centrul atenției o lume a frontului și a personajelor tragice. $\mathrm{Cu}$ influență a realismului socialist, scriere caracteristică pentru anii de după război, romanele lui se apropie cu un pas mai aproape de modernism. În povestirile și romanele lui Traian Doban, temele cetrale sunt întâmplările reale din viața satului românesc din Serbia redate cu un șir de detalii realiste: mentalitatea tinerilor, junalul de război, realitatea autentică, note autobiografice dar și gastronomia tradiţională românească. Romancierul folosește tehnica narativă a povestirii în povestire iar istoricul literar Ştefan N. Popa consideră că idealizarea personajelor din romanul de factologie istorică, ,în contextul discursului actualității cronologice apare ca o construcție nefirească ce intră în pozitivismul netipizat" (Popa, 1977: 131). Radu Flora, prin romanele sale pendulează între tradiționalism și modernism. La început, opera sa fiind mai conservatoare, clasică iar apoi trece la o scriere, în mare parte autobiografică, 
apropiindu-se de modernism. Primul roman al său, Crucea, publicat în foileton în săptămânalul „Libertatea”, între anii 1951-1952, este o scriere cu totul tradiționalistă, reprezentând un tablou al satului bănățean. Imediat ce trece la al doilea roman al său Când vine primăvara, trece la autobiografism și vorbește la persoana I, introducând cititorul în lumea liceului și internatului vârșețean, a vieții studențești din perioada interbelică. Prin trilogia Capcana (1978), Vârtejul (1980) și Zidul (1983), Radu Flora realizează „o frescă a satelor românești bănățene din perioada interbelică" (Agache, 2010: 96). Autorul scoate în evidență în aceste romane starea politică, educația elevilor, naționalismul, experiența sa din contactul cu învățătorii contractuali veniţi din România în perioada de dinainte de cel de-al doilea război mondial. Cu un fundal etnogeografic, multietnic al satelor bănățene, autorul scrie o proză a cărui fir epic este inspirat, în mare măsură, din social. El zugrăvește realităţile satelor bănățene născocind o galerie de tipologii specifice ruralului bănățean: directori de școală, învățători, preoți, primari, notari, țărani, de naționalitate română, sârbă, maghiară și de alte naționalități.

Prin romanul Noapte de hârtie (1971) de Slavco Almăjan și Săptămâna (1976) de Costa Toader, un scriitor despre care nu s-a scris foarte mult în literatura română din Voivodina, ne apropiem de modernism, prin limbajul curățit de regionalisme, sârbisme și bănățenisme dar cu un limbaj nou, al presei românești. În roman apare intelectualul din lumea modei sau a tehnicii, îndepărtat de satul său natal din nevoia de a-și căuta o muncă adecvată după terminarea școlilor. Romanuleseu, Noaptea de hârtie, ,axat pe simboluri, idei și întrebări” (Agache, 2010: 215), un „pseudo-roman” și o meditaţie a eului naratorului ,asupra condiţiei existenţei și creaţiei asupra robotizării individului” (Ibidem) aduce în faţa cititorului personaje bizare, o descriere a unui cotidian violent și banal unde omul devine mașina timpului, iar sentimentele sale și stările de neliniște care izbucnesc din subconștientul lui ca și fanteziile erotice descoperă pe acest om ,în permanentă căutare a realului” (Popa, 1997: 162), femeia fiind o fantasmă care-și destăinuie tribulațiile sufletești dor ,în pat”. Limba vorbită de Slavco Almăjan este la nivelul limbii standard, iar graiul bănățean și cuvintele sârbești sunt folosite cu atenție, conștient de întrebuințarea lor. Teodor Munteanu prin Marele secret, genul de roman antiutopic de tip orwellian sau de genul ,înapoi în viitor", prin care a debutat în 1986 la Editura Libertatea, un roman „de anticipație” (Barbu \& Ciobanu, 2013: 147), care „din perspectiva de azi devine [...] posibil și real” atunci când în centrul atenției este viața omului dirijată de alte lumi, alte centre atotştiutoare de comandă, ivizibile și suspecte. O lume robotizată, computerizată care schimbă viața omului transformându-l într-un pion al însăşi vieți, condus după voia ei și influențată de putere invizibilă pe care nu o poate evita și din care nu poate evada, trăind într-o 
„realitate cronico-absurdă” (Mengher, 2000: 195). Abaterea de la viața normală a unui om presupune pierderea identității proprii, viața lui fiind supusă transformării anticipând „un posibil viitor utopic” (Barbu \& Ciobanu, 2013: 148). O aspiraţie ideală a romancierului era de a ne oferi o posibilă viață cu anumite caracteristici ale unei lumi de construit într-un viitor utopic în care ar circula creaturi înzestrate numai cu atributele pure ale bunătăţii, demnităţii și eticii. Autorul ne aduce în faţa noastră un roman modern, cu scene uneori fantastice, uneori reale, idealul căutând în posibilitata trăirii unei altfel de vieți a cărui destin este de discutat.

George M. Frișcan, a publicat două volume de proză scurtă la Editura „Libertatea”: Navetiştii (2003) și Căldura sufletului (2007) și un roman De ce s-a dus Helen la mănăstire? (2012), prin care a surprins un subiect aproape inedit în literatura din Voivodina, amintirile din tren din perioada socialistă în România, pe relația București-Constanța. În această primă carte, precum și în celelalte două, autorul și-a propus să ne redea relațiile interumane și psihologice ale personajelor, începând cu navetiștii, „o categorie de oameni care-şi petrec o parte din viaţă în Câmpia Bărăganului” (Petrovici, 2002: x) și continuând cu consătenii săi din Torac, cunoscuții din Vârșeț din perioada timpurie a vieții sale, în volumul doi. Unicul roman al său, un roman de familie cu o tematică modernă de dragoste și cu intrigi simple pe care eroii lui încearcă să uite, îmbrățișând momentele îmbibate de dragoste și armonie, conștienți că într-o relație de iubire conjugală este nevoie de multă reținere și răbdare, nerăbdarea ar putea uneori să strice toate visele unui cuplu. Numai un singur cuvânt spus cu asprime poate împiedica pentru multă vreme complicatul proces de contopire a sufletelor. Iată de ce ambele părți trebuie să-și dorească cu tot dinadinsul o căsnicie fericită și împreună să depășească orice obstacol care le stă în calea fericirii. Anii de după Războiul al Doilea Mondial și relațiile dintre numeroasele popoare europene, cu mentalități și educaţie diferite, obiceiuri și tradiții, sunt redate de autor descoperind greutăţile cuplului îndrăgostit să înţeleagă unele obstacole puse în cale chiar de propria lor soartă. Moartea subită a soției răpusă de boală, îl obligă pe soț să păstreze în amintire acele momente minunate petrecute alături de aleasa sa, arătând publicului cititor că o dragoste adevărată poate să arate calea unei veșnice trăiri în paradisul gândurilor. Romanul fără un final definit, deschide drumul unei multitudini de posibilități, unei credințe în iubirea veșnică, în puterea dragostei de a fi mai tare decât moartea.

Mai târziu, în Voivodina apar și alte romane care avansează semnificativ spre teritoriul vieţii familiale, care prin limbaj elocvent și cursiv, se înscriu în circuitul literar din această zonă. Romanele Eugeniei Bălteanu sau ale Mărioarei Stojanović „confirmă convingerea că personajul feminin și-a asigurat acel loc pe care-1 considerăm reper în proza noastră" (Ciobanu \& Barbu, 2013: 175). În 
romanele Mărioarei Stojanović, Veronica (2008), Vorbește-mi despre mama (2012) și Fereastra de sub nori (2014), imaginea femeii este înţeleasă în sensul dezirabil al așteptărilor prestabilite de societate. Romanele ei dar și destinul eroilor săi se formează în funcţie de cultură și de regulile prestabilite de societate, care vor influența într-o mare măsură destinul lor. Femeia, o ființă fragilă care crede în iubire, precum copilul în magie, ,va accepta ispitele vieții văzând, în această luptă a sa cu sine și cu dimensiunile dificile ale subconștientului, o nouă şansă, un nou început" (Almăjan, 2014: xx). În momentul când magia se transformă în suferinţă, ea este atât de debusolată încât e în stare să facă orice să aibă aripi să zboare, acceptând să fi e responsabilă față de sine și față de cei din jur. Femeia are nevoie de cuvinte frumoase, de tandreţe iar circumstanțele sociale ale trilogiei sale duc la alunecarea din viaţa reală a eroilor, în iluzie, ea fiind „fără margini, iar fereastra vieții, de sub imensitatea cerului, odată deschisă, ị̂si oferă zborul spre nesfârșire" (Ciobanu, 2014: xx). Satul bănățean este reînviat în romanele Mărioarei Stojanović, prin prisma amintirilor și realităților ,uşor adormite” (Ibidem) în odăile trecutului. Spațiul patriarhal al satului bănățean impune bariere de manifestare liberă a trăirilor sufl etești, iar lupta pentru existență a femeii nu este altceva decât „,confirmarea libertății şi a vieții împlinite” (Barbu\&Ciobanu, 2013: 175). Romanele celor două romanciere, Mărioara Stojanović și Eugenia Bălteanu se pot considera pe de o parte romane de dragoste, pe de altă parte de familie, în care femeia este în continuă luptă pentru existență, osândită la normele impuse de societatea modernă, din care ar vrea să evadeze scufundându-se uneori în suferință iar alteori în vis. Totuși, „starea de somn și visul ei e plin de coșmar" (Ibidem: 176), încât sensul căutării libertăţii și a vieții împlinite trebuie căutate în altă parte unde ar avea un vis pentru care să trăiască, un scop, un sens. Prin ,socialul” ultimelor romane feminine publicate în Voivodina, înţelegem cadrul restrâns al familiei cât şi cel lărgit al grupului etnic, cultura din care facem parte, calea cea mai bună de urmat pentru realizarea și împlinirea fericirii autentice.

Neologismele englezești şi expresiile în limba engleză din lumea muzicii, modei, din limbajul uzual al unei lumi moderne și mondene, sunt materialul de construcție al romanelor Eugeniei Bălteanu, Mona (2005), Tangoul (2008), Trei anotimpuri (2009), Speranța (2011), Scrisori din Pasadena (2014) în care eroii trăiesc adesea în „planuri duble” și în lumi paralele, viaţa de acum și viaţa din trecut. Ingeniozitatea prozatoarei este de a manevra astfel epicul, evenimentele și comportamentele umane, încât să sugereze într-adevar apartenenţa acestora la mai multe lumi. Viaţa pentru adult poate fi înțeleasă asemenea jocului pentru copil, dar aşa cum nu toate jocurile au un sens anume, copilul găsind plăcere, pur și simplu, în acţiunea jocului, la fel se poate dezvălui și viaţa adultului: scopul îi poate scăpa, 
ţelul poate fi omis, dar viaţa este o plăcere în însăși experienţa de a trăi. Și asemenea copilului, cu cât este el mai constructiv în a-și crea jocul propriu și a se bucura pe măsură de propria sa creaţie, la fel și viaţa i se poate dezvălui mai interesantă adultului cu cât e mai cercetător, imaginativ și inovativ în stilul său de viaţă. Eroii Eugeniei Bălteanu sunt puși chiar în această ipostază, de căutare a sensului vieții. Fericirea socială nu poate fi dobândită în urma construcţiei defectuoase a unui sistem de raportare la ceilalţi deprins dintr-o familie destrămată, iresponsabilă, imatură. În sânul familiei constructive persoana învaţă și îmbunătăţeste, amplifică, perfecţionează atitudinile de toleranţăa, de solidaritate, de compasiune faţă de ceilalţi: prietenii sau colegii învaţă să se ajute între ei, să aibă răbdare unul cu altul, să joace cinstit și mai ales învaţă ce înseamnă să pierzi. Aceste rosturi sunt descoperite de eroii romanelor doar atunci când și-au dat seama de greșelile anterioare, datorită cărora viața tuturora a luat-o în alte sensuri.

Romanele moderne din Voivodina pendulează între explicabil şi inexplicabil, între real și vis, între posibil și imposibil, rezultând de aici o proză de rafinate dozaje, asociind expert livrescul și puterea de descripţie realistă, poezia și psihologia. $\mathrm{Cu}$ totul într-o altă direcție o ia romanul de debut al tinerei scriitoare Alexandra Goica, Jurnalul soldatului rănit, apărut în 2014 la Editura Libertatea din Panciova, considerat mai întâi un roman psihologic, scris la persoana întâi și care deschide un nou capitol al romanului modern voivodinean, a cărui tematică este, pe de o parte războiul propriu-zis, ,războiul și ororile sale, multitudinea de situaţii neașteptate, spectacolul unei vieți de om, relația individ, familie și societate, subconștientul și destinul uman, complexitatea trăirilor sufletești și încercarea de elucidare a tăinuitelor compartimente ale subconștientului, metamorfoza, chipului uman" (Berlovan, 2014: 7), iar pe de cealaltă parte lupta interioară a soldatului erou. Romanul este împărțit în trei capitole, fiecare capitol cu tribulațiile sufletului unei alte persoane. La început descoperim lupta sufletească a protagonistului acestui roman, a unui soldat rănit găsit pe câmpul de luptă, în al doilea capitol suferința Mariei, mama soldatului, ajunsă în spital suferind de o boală grea iar cel de-al treilea capitol este dedicat Anei, soției soldatului. De la câmpul de luptă, unde e rănit, până la plecarea în străinătate a eroului, al cărui nume nu-l știm, au trecut mulți ani, autoarea trece de la o perioadă de timp la alta, foarte repede, asemeni trecerii vieții. Pe soldat îl vedem rănit pe câmpul de luptă căutând să evadeze din acest câmp, un câmp al destinului lui, precum îi este și sufletul lui - gol și plin de speranțe de a revedea persoanele dragi. Familia rămasă acasă, lăsată în soarta ei, soția sa iubită, lăsată să supraviețuiască în singurătate, o descoperim ca pe un personaj pus în planul doi. Nimic din ceea ce se petrece în familie nu vedem, doar prin prisma trăirilor neașteptate ale protagonistului pe marginea subconștientului. 
„Dincolo de spațiul jurnalului, viața protagonistului clocotește de trăiri neașteptate, imprevizibile și pilduitoare pentru fiecare om" (Ibidem). Din realitate - în vis, din trecut - în prezet sau viitor, autoarea pune cele mai serioase probleme ale existenței și ale supraviețuirii unui om pe tărâmuri străine, care, în căutare de bunuri materiale uită că vremea este trecătoare și că, fără să-și dea seama întreaga viață a petrecut-o departe de familie. Nicio bogăție materială nu are valoare dacă soția și copiii nu știu nimic despre soarta lui năprasnică. Soția 1-a plâns ani de-a rândul, a purtat haine de doliu trăind în sărăcie, iar când acesta s-a anunțat după mulți ani, a ars cu nepăsare scrisoarea de la el. În urma lecturii romanului, cititorul rămâne cu niște întrebări fără răspunsuri, deschizându-i, însă, fantezia, făcâdu-1 să propună singur sfârşitul cărții și locul unde s-a întâmplat acțiunea sau chiar despre ce război este vorba în roman. Autoarea a vrut prin pana ei de tânără romancieră să descopere un război al sentimentelor interioare a fiecărui om găsit singur pe câmpul de luptă, în țărmuri necunoscute, lucru justificat prin următoarele cuvinte: ,Ideile filosofice care apar în text (acestea fiind: probleme ontologice, existențialism, antropologism) nu sunt decât simplele preocupări cu care se luptă orice muritor de rând în viaţa de zi cu zi, fi e conştient sau inconștient" (Goica, 2014: 9). Şanțurile găsite pe câmpul de luptă simbolizează prăpastiile sufletești în care eroul nostru cade de fiecare dată când îl năpândește dorul de familie, suferința și nebunia, gândurile că poate e bolnav de boala de care a suferit și mama sa Maria. Eroul principal este urmărit de autoare prin analiza crizelor de conștiință și de comportament, ca într-o adevărată fișă medicală. Fără să înțelegem de ce a fugit de la familia sa, rămânem cu speranța întâlnirii soților, autoarea lăsându-ne fără răspuns, dorind astfel să ne pună pe gânduri și să înțelegem din context psihologia ascunsă și misterioasă a acestui om singur. Astfel putem să înțelegem mai bine profilul soldatului din fiecare colț al lumii, cu propriile zbateri sufletești sau gândurile și meditaţiile noastre sau ale fiecăruia care luptă cu propriul suflet, iar soldații, considerați niște luptători disperați, niște inși răniți sufletește atunci când se trezesc într-o lume vitregă și necunoscută, niște inadaptați, oameni fără rădăcini. Este un roman-jurnal, de factură naturalistă, unde eroul principal apare cu monologuri interioare, de conștientizare a fricii, iar destinul dramatic ale eropului are la bază neliniștile și frământările omului confruntat cu propriul destin, alegând viața în izolare și renunțare la frumusețiile vieții în sânul familiei. Soldatul rănit despre care este vorba în acest roman poate fi înlocuit cu soldatul pierdut în prăpăstiile vieții sau cu tribulațiile sufletești ale unui soldat inadaptat pe tărâm străin.

Romanul de față este un debut extraordinar de reuşit, cu care ne-am dat seama că literatura română din Voivodina a reușit să pășească în secolul XXI cu o generație promițătoare de tineri scriitori douămiiști iar romanul din Voivodina intră 
într-o nouă epocă în care se cristalizează o nouă generație de romancieri și noi specii de romane în care se scoate în evidență, mai întâi identitatea românească din această parte a Europei, limba autentică din satele bănățene și mentalitatea românului care trăiește în alt mediu decât cel al limbii materne. Legat sufletește de țara-mamă, cu iubire veșnică de țara unde s-au născut strămoșii lui, scriitorul voivodinean scrie un roman inedit în care protagoniștii lui joacă un joc al vieții și al destinului lor.

Virginia Popović

\section{ROMANIAN NOVEL IN VOJVODINA: THEMES AND MOTIFS}

\section{Summary}

Every literature has its own beginning and directions with which it manifests and unites poets and prose writers based on specific literary characteristics. Each literary direction has its own program or a manifest published in the first issue of the magazine that promotes his ideology. Regarding Romanian literature from Vojvodina, literary historians fixed it's beginings, starting with the fifth decade of the last century, the appearance of the first literary magazine in the region. Literary historians do not talk about the existence of Romanian novels in Vojvodina before 1945th. Starting with the ideas of the literary historians, by publishing the first chapters of novels in cultural magazines of Vojvodina of the 50's, is considered as the beginning of the Romanian novel in Vojvodina. In this paper we will try to make a division of the Romanian novel in Vojvodina for the first time and to point out the most important topics and motives in the development of the novel, characteristic for the Romanian rural area of Banat.

Keywords: novel, Romanian literature in Vojvodina, motifs, themes

Вирђинија Поповић

\section{РУМУНСКИ РОМАН У ВОЈВОДИНИ: ТЕМЕ И МОТИВИ}

\section{Резиме}

Свака књижевност има свој почетак и књижевне правце у којима се манифестује и који уједињују песнике и прозне писце на основу специфичних књижевних карактеристика. Сваки књижевни правац има свој програм или манифест објављен у првом броју часописа који промовише његову идеологију. Што се тиче румунске књижевности из Војводине, књижевни историчари су фиксирали њен почетак тек у петој деценији прошлог века појавом првих књижевних часописа на овим просторима. Књижевни историчари не говоре о постојању румунских романа у Војводини пре 1945. године. Ако крећемо од идеја књижевних историчара, 
објављивање првих одломака романа у часописима за културу војвођанских Румуна педесетих година прошлог века, сматра се почетком румунског романа у Војводини. У овом раду ћемо покушати да по први пут направимо поделу румунског романа у Војводини и да укажемо на најзначајније теме и мотиве у развоју романа, својствене румунском руралном простору Баната.

Кључне речи: роман, румунска књижевност у Војводини, мотив, тема

\section{REFERINȚE BIBLIOGRAFICE:}

Agache, C. (2010). Literatura română din Voivodina. Panciova: Editura Libertatea. Baba, Ioan (2017). Banatul în memoria clipei. Panciova: Editura Libertatea. Barbu, V. \& Ciobanu, N. (2013). 65 de ani de beletristică (1947-2012). Panciova.. Editura Libertatea.

Cosma, Anton (1988). Romanul românesc contemporan. București: Editura Eminescu.

Dărăbuș, C. \& Popović, V. (2012). Literatura de limba română din Serbia și antropologia culturală. Novi Sad, Fond Europa, Cluj-Napoca: Risoprint.

Filip, E. (1998). Ultimul sentimentalist. Miodrag Miloş la 65 de ani, apud Metonimia râulenilor. Miodrag Miloș la 65 de ani, volum omagial, Colecția „Lumina”.

Flora, Radu (1976). Rumunska književnost u Vojvodini. Novi Sad: Matica srpska.

Frișcan, George M. (2002). Navetiştii. Panciova: Editura Libertatea.

Goica, A. (2014). Jurnalul soldatului rănit. Panciova: Editura Libertatea.

Iovanovici, R. (1998). Miodrag Miloș. Încercarea de a zbura, apud Metonimia râulenilor. Miodrag Miloș la 65 de ani, volum omagial, Colecția „Luna”.

Juică, B. (2012). La confluenţa a două culturi literatura română din Voivodina: (1945-1989), Zrenianin: ICRV [i. e.] Institutul de Cultură al Românilor din Voivodina;

Magdu, L. (1976). Abateri de la normele limbii literare (practicată la noi în Voivodina), apud Contribuţii la istoria culturală a românilor din Voivodina, Vol. III;

Mengher, I. (2000). Lumina: (1947-1997): studiu monografic. Editura Libertatea, Panciova.

Popa, Ștefan N. (1997). O istorie a literaturii române din Voivodina. Panciova: Editura Libertatea.

Popović, M. (2016). Opinii și reflecții. Proza românească din Voivodina. Panciova: Editura Libertatea. 